\title{
Differentiation of Rheumatoid Arthritis From HCV Infection: Rheumatoid Factor, Anti-Cyclic Citrullinated Peptide or Anti-Mutated Citrullinated Vimentin?
}

\author{
Romatoid Artritin HCV Enfeksiyonundan Ayrılmasında Romatoid Faktör, \\ Anti-Siklik Sitrüline Peptid ve Anti-Mutated Sitrüline Vimentinin Yeri
}

\author{
Ece Kaptanoğlu', Işılay Nadir², Zahir Bakıcı ${ }^{3}$, Emrullah Hayta $^{4}$, Mehmet Türkmen $^{1}$, \\ Hafize Sezer ${ }^{5}$, Sami Hizmetli ${ }^{1}$, Hasan Elden ${ }^{1}$ \\ ${ }^{1}$ Cumhuriyet Üniversitesi Tıp Fakültesi, Fiziksel Tıp ve Rehabilitasyon Anabilim Dalı, Sivas, Turkey \\ ${ }^{2}$ Numune Devlet Hastanesi, Gastroenteroloji Bölümü, Sivas, Turkey \\ ${ }^{3}$ Cumuriyet Üniversitesi Tıp Fakültesi, Mikrobiyoloji Anabilim Dalı, Sivas, Turkey \\ ${ }^{4}$ Numune Devlet Hastanesi, Fizik Tedavi Bölümü, Sivas, Turkey \\ ${ }^{5}$ Cumhuriyet Üniversitesi Tıp Fakültesi, Biyoistatistik Bölümü, Sivas, Turkey
}

\begin{abstract}
Objective: Differentiation of rheumatoid arthritis (RA) from other diseases with joint involvement such as hepatitis- $C$ virus (HCV) infection represents a diagnostic problem. In addition to the rheumatoid factor (RF), more specific and sensitive autoantibodies are under evaluation in recent years with conflicting results. In this study, we tested the diagnostic value of rheumatoid factor, anti-cyclic citrullinated peptide (anti-CCP) and antimutated citrullinated vimentin (anti-MCV) in distinguishing RA from hepatitis $C$ patients.

Materials and Methods: Sera of 34 RA patients and 30 hepatitis $\mathrm{C}$ patients were tested for RF, anti-CCP anti-MCV. Disease activity was determined by disease activity score (DAS-28) 28 in RA and by modified Knodell score in hepatitis $C$ patients. Extra-articular involvement in RA and rheumatologic involvement in hepatitis $C$ patients were documented.
\end{abstract}

Results: In roc analysis, area under curve (AUC) was the highest in anti-CCP. Sensitivity and specificity was $82 \%$ and $53 \%, 79 \%$, and $96 \%$ and $70 \%$, and $73 \%$ for RF, anti-CCP and anti-MCV respectively. DAS-28 has a weak correlation with $\mathrm{RF}(r=0.406)$, anti-CCP $(r=0.433)$, and anti-MCV $(r=0.453)$. There was no difference between the patients in autoantibody levels regarding extra-articular involvement and DAS-28 in RA, and joint involvement in hepatitis $C$ patients.

Conclusion: Anti-MCV antibodies may be useful in distinguishing RA however it seems to have no additional value over anti-CCP or RF in hepatitis C patients. Anti-CCP antibodies are more reliable in diagnosis of RA due to their high specificity.

(Turk J Rheumatol 2010; 25: 19-23)

Key words: Rheumatoid arthritis, HCV, rheumatoid factor, antiCCP, anti-MCV

Received: 02.06.2009

Accepted: 26.09.2009
Özet

Amaç: Romatoid Artriti (RA) hepatit C enfeksiyonu gibi eklem tutulumu olan diğer hastalıklardan ayırmak zordur. Romatoid faktörün (RF) yanı sıra son yıllarda daha duyarlı ve özgül otoantikorlar araștırılmaktadır ve çelișkili sonuçlar vardır. Bu çalıșmada biz RF, anti-siklik sitrüline peptid (CCP) ve anti-mutated sitrüline vimentinin (MCV) RA ve hepatit C enfeksiyonunu ayırmada tanısal değerlerini araștırdık.

Yöntem ve Gereçler: Otuzdört RA'lı ve 30 hepatit C'li hastada RF, anti-CCP ve anti-MCV çalıșıldı. RA'da hastalık aktivitesi DAS-28 ile hepatit C'de ise Knodell skoru ile değerlendirildi. RA'da eklemdıșı tutulum ve hepatit C'li hastalarda eklem tutulumu değerlendirildi.

Bulgular: Romatoid artritli ve hepatit C'li hastalar karșılaștırıldığında eğri altındaki alan en yüksek anti-CCP'de idi. Duyarlılık ve özgüllük RF için \%82 ve \%53, anti-CCP için $\% 79$ ve $\% 96$ ve antiMCV için $\% 70$ ve $\% 73$ idi. DAS-28 ile RF ( $r=0.406)$, anti-CCP $(r=0.433)$ ve anti-MCV $(r=0.453)$ arasında zayıf bir ilișki vardı. RA'da eklem dıșı tutulum, DAS-28 ve hepatit C'li hastalarda eklem tutulumu dikkate alındığında olgularda otoantikorlar açısından fark bulunmadı.

Sonuç: Anti-MCV antikorları RA'nın tanınmasında kullanılabilir ancak hepatit C'li hastalar söz konusu olduğunda anti-CCP veya RF'nin performansına bir katkıda bulunmamaktadırlar. Yüksek özgüllükleri düșünülecek olursa, anti-CCP antikorları RA'nın tanısında daha güvenilir görünmektedirler.

(Turk J Rheumatol 2010; 25: 19-23)

Anahtar sözcükler: Romatoid artrit, HCV, romatoid faktör, antiCCP, anti-MCV

Alındığı Tarih: 02.06.2009 Kabul Tarihi: 26.09.2009

Address for Correspondence: Dr. Ece Kaptanoğlu, Cumhuriyet Üniversitesi Tıp Fakültesi, Fiziksel Tıp ve Rehabilitasyon Anabilim Dalı, Sivas, Turkey Phone: +903462580681 E-mail: ekaptan2006@gmail.com 


\section{Introduction}

Rheumatoid arthritis (RA) is characterized by inflammation of joints resulting in severe disability. Early diagnosis and treatment is crucial on this account. In addition to clinical features, auto-antibodies are also of special interest because of their role in discriminating the disease. Although rheumatoid factor (RF) was the gold standard more specific and sensitive auto-antibodies are being searched in recent years.

Antibodies against citrullinated peptides, the peptides post-translationally modified by the conversion of arginin to citrulline, have gained importance with the contention to be specific serological markers for RA $(1,2)$. Citrullination causes protein unfolding possibly altering protein structure resulting in aberrant recognition in the immune system. They are assumed to be triggered in the context of genes that confer susceptibility to RA and by environmental agents (1). Being as sensitive as RF and even more specific, anti-cyclic citrullinated peptide (anti-CCP) is now candidate for crown of RF. Anti-CCP has a comparable sensitivity to RF $(50-75 \%)$ with a higher specificity $(90-95 \%)(1,3)$. However, there are also contradictory results related to $\mathrm{HCV}$ infection where specificity of anti-CCP for RA is questioned $(4,5)$.

$\mathrm{HCV}$ infection is usually asymptomatic and may be detected incidentally; it also induces immunological extrahepatic manifestations including arthralgia and arthritis which can mimic RA, and discrimination is really difficult without observing the erosions (6). Along with anti-CCP, a new marker, anti-mutated citrullinated vimentin (antiMCV) came into question. Anti-MCV antibodies have been searched mainly in connective tissue diseases recently (7-9). In a meta-analysis, sensitivity and specificity of anti-MCV antibody were reported as between $0.64-0.84$, and 0.79 0.96 respectively which almost is equal to that of anti-CCP in RA (8). Unfortunately, the role of this autoantibody in discriminating RA from hepatitis C patients is not clear as there is only one study which included hepatitis $C$ patients as controls, revealed discouraging results (10).

In this study we aimed to investigate the diagnostic value of RF, anti-CCP and anti-MCV in differentiating RA from HCV associated rheumatological manifestations.

\section{Materials and Methods}

Thirty-four RA patients, classified according to the ACR 1987 revised criteria (11) were consecutively recruited from the outpatient rheumatology clinics between October 2008 and February 2009. Disease activity score 28 (DAS 28) was evaluated and scores $\leq 3.2$ were accepted as mild active (12). Disease, duration and extra-articular involvement were also documented.

Thirty patients having hepatitis $\mathrm{C}$ infection with positive anti-HCV antibodies and HCV RNA were included as the control group. Histological activity index and fibrosis were evaluated according to the modified Knodell score in hepatitis C patients (13). Patients with disease activity score $\leq 3$ were evaluated as mild active and others as active. Fibrosis was evaluated as grade 1-3.

Serum samples were stored at $-80^{\circ} \mathrm{C}$ until analysis. All results were obtained by blinded laboratory technicians.

Anti-MCV and anti-CCP were detected by commercially available enzyme linked immunosorbent assays. Results are expressed as U/ml. Anti-MCV was evaluated with Orgentec kit, Germany, (instrument: Triturus, Italy). Anti-CCP was performed with Aeskulisa (uses second generation peptides, CCP2), Germany kit (instrument: Triturus, Italy).

Rheumatoid factor was studied with Becman Coulter, USA kit (instrument: Becman coulter image, USA), by nephelometry.

Erythrocyte sedimentation rate (ESR) and C-reactive protein (CRP) were studied in patients with RA.

Statistical analysis was performed by Medcalc version 9.2.1.0. Significance was assumed at $p<0.05$. Receiver operating characteristic (roc) curve analysis was obtained for determining diagnostic values of assays. Optimal cut off values were obtained by the maximum value of sensitivity + specificity-1.

To compare the data among RA and hepatitis C patients, Mann Whitney $U$ test was used. In searching the difference between patients with and without extraarticular involvement, mild and severe active patients in RA and hepatitis C patients with and without arthralgia, Fisher's exact test was performed. Pearson correlation was used for searching the correlation between the parameters.

The study protocol was approved by the local ethics committee.

\section{Results}

Demographic, clinical and serological parameters of the RA and hepatitis C patients are given in Table 1 .

The mean $\pm S D$, median, minimum and maximum values of the antibody assays are given in Table 2. There were significant differences between the RA and hepatitis $C$ patients (Table 2). The differences between RA and hepatitis $C$ patients regarding $R F$, anti-CCP and anti-MCV were at the levels of $p=0.001, p=0.0001$, and $p=0.0001$, respectively.

As to the diagnostic value of RF, anti-CCP and anti-MCV, we performed ROC curve analysis for discriminating RA from hepatitis $C$ patients (Figure 1 ). The AUC, sensitivity and specificity values are given in Table 3 . The difference in AUC between anti-CCP and RF $(p<0.001)$ and between anti-CCP and anti-MCV $(p=0,001)$ were significant (Figure 1). There was no difference between RF and anti-MCV. The optimum cut-off values are given in the Table 3 .

In RA group, anti-MCV was found to be correlated with anti-CCP $(r=0,736, p<0.001)$, RF $(r=0.365, p<0.05)$ and DAS-28 $(r=0,453, p<0.05)$. DAS-28 was also correlated with Anti-CCP $(r=0.433, p<0.05)$ and $\operatorname{RF}(r=0.406, p<0.05)$. Anti-CCP and RF were correlated $(r=0.579, p<0.001)$. In hepatitis $C$ patients, no correlation was observed.

In RA group there were seven patients with extraarticular involvement. There was not a statistically 
Table 1. Demographic, clinical, and serological parameters of the study groups (mean $\pm S D$ )

\begin{tabular}{|c|c|c|}
\hline & $\begin{array}{l}\text { Rheumatoid arthritis } \\
(n=34)\end{array}$ & $\begin{array}{l}\text { Hepatitis C patients } \\
\qquad(n=30)\end{array}$ \\
\hline Age, years & $48.91 \pm 11.64$ & $57.73 \pm 11.62$ \\
\hline Male / female & $11 / 23$ & $8 / 22$ \\
\hline ESR & $\begin{array}{c}30.11 \pm 26.32 \\
\text { (median: } 20.50 \text { min: } 5 \text { max: } 105 \text { )* }\end{array}$ & - \\
\hline CRP & $\begin{array}{c}14.33 \pm 13.48 \\
\text { (median: } 10.95 \text { min: } 1 \text { max: } 62,1 \text { )* }\end{array}$ & - \\
\hline DAS-28 & $3.72 \pm 0.92$ & - \\
\hline Disease duration (year) & $\begin{array}{l}5.56 \pm 4.50 \\
\text { (median: } 4 \text { min: } 1 \text { max: } 20 \text { )* }\end{array}$ & $\begin{array}{c}3.37 \pm 2.39 \\
\text { (median: } 2.5 \text { min: } 1 \text { max: } 11 \text { )* }\end{array}$ \\
\hline RF positivity & $28(82.4 \%)$ & $14(46.7 \%)$ \\
\hline Anti-CCP positivity & $27(79.4 \%)$ & $1(3.3 \%)$ \\
\hline Anti-MCV positivity & $24(70.6 \%)$ & $9(30 \%)$ \\
\hline
\end{tabular}

Table 2. Quantitative results of the assays

\begin{tabular}{lllll}
\hline Assay & & Mean \pm SD & $\begin{array}{l}\text { Median } \\
\text { (min-max) }\end{array}$ & Statistics* \\
\hline RF & RA $(n=34)$ & $179.02 \pm 300.86$ & $40.05(11-1220)$ & $p=0.001$ \\
Anti-CCP & Hepatitis C $(n=30)$ & $50.78 \pm 122.50$ & $19(7-684)$ & $p=0.0001$ \\
& RA $(n=34)$ & $138.86 \pm 121.05$ & $93.5(2.28-300)$ & \\
Anti-MCV & Hepatitis C $(n=30)$ & $2.34 \pm 3.60$ & $1.04(0.34-18,3)$ & $p=0.0001$ \\
\hline
\end{tabular}

*Mann Whitney $U$ test was used

RF: Rheumatoid Factor, Anti-CCP: anti-cyclic citrullinated peptide, Anti-MCV: antimutated citrullinated vimentin, SD: standard deviation, min: minimum, max: maximum

significant difference between RA patients with and without extra-articular involvement regarding $\mathrm{RF}$, anti-CCP and anti-MCV levels (Fisher's exact test was used, $\mathrm{p}>0.05$ ).

According to DAS 28 score, RA patients were classified as mild and severe active disease with the cut-off value of 3,6 . There was also not a significant difference between these groups regarding RF, anti-CCP or anti-MCV (Fisher's exact test was used, $\mathrm{p}>0.05$ ).

Arthralgia was present in $10(33 \%)$ of the hepatitis C patients. Wrists, elbows, shoulders, knees and ankles were involved predominantly. No significant difference between hepatitis $C$ patients with or without arthralgia regarding the autoantibody assays was detected (Fisher's exact test was used, $\mathrm{p}>0.05$ ). Because of elderly age and rejection of the process, biopsy was performed only in 21 patients. There were only 2 patients with histological activity index $\leq 3$. Fibrosis was observed as grade 1 in 15 patients, grade 2 in 5 patients, and grade 3 in 1 patient.

\section{Discussion}

In our study we investigated the diagnostic value of RF, anti-MCV and anti-CCP antibodies in distinguishing RA from HCV infection.
In RA group, RF was positive $82.4 \%$, whereas anti-CCP was positive $79.4 \%$ and anti-MCV was positive $70.6 \%$ (Table 1). In hepatitis C patients, RF was positive in $46.7 \%$, anti-CCP was positive in $3.3 \%$, and anti-MCV was positive in $30 \%$ of the group. There were differences between the RA and hepatitis $C$ patients regarding RF, anti-CCP and anti-MCV levels (Table 2).

Anti-MCV was strongly correlated with anti-CCP however the correlation of anti-MCV with RF was very weak. This finding is consistent with the literature $(7,14)$.

Anti-MCV is suggested to be positive in anti-CCP negative RA patients $(8,15)$. In our study, in only 2 RF negative patients both anti-CCP and anti-MCV were positive and in those 7 anti-CCP negative patients, anti-MCV was also negative. Although the limited number of our cases is discouraging for extrapolating, looking for anti-MCV in RF negative cases may be helpful, but it does not seem to be useful for those cases with negative anti-CCP.

In roc curve analysis, AUC was highest at the anti-CCP, sensitivity was $79 \%$ and specificity was $96 \%$ (Table 3, Figure 1). However the specificity of RF and anti-MCV was lower. The sensitivity and specificity of RF and anti-MCV were $82 \%$ and $53 \%$, and $70 \%$ and $73 \%$, respectively. Optimum cut-offs were determined as 7, 2, 20, 6 and 27, 4 for anti-CCP, RF and anti-MCV respectively. 
Table 3. Diagnostic value of the assays at manufacturers' and optimal levels for rheumatoid arthritis $(n=34)$ and hepatitis $C$ patients $(n=30)$.

\begin{tabular}{lccccccc}
\hline Assay & AUC 95\% Cl & \multicolumn{3}{c}{ Manufacturers' cutoff } & \multicolumn{3}{c}{ Optimal cutoff } \\
& & cutoff & Sn (\%) & Sp (\%) & cutoff & Sn (\%) & Sp (\%) \\
\hline RF & $0.732^{*}$ & 20 & 82 & 53 & 20.6 & 82 & 56 \\
Anti-CCP & $(0.609-0.856)$ & & & & & & \\
& $0.974^{*}$ & 12 & 79 & 96 & 7.2 & 88 & 93 \\
Anti-MCV & $(0.944-0.999)$ & & & & & & \\
& $0.811^{*}$ & 20 & 70 & 73 & 27.4 & 70 & 86 \\
& $(0.702-0.920)$ & & & & & & \\
\hline
\end{tabular}

RF: Rheumatoid Factor, Anti-CCP: anti-cyclic citrullinated peptide Anti-MCV: antimutated citrullinated vimentin, AUC: area under curve, Sn: sensitivity, Sp: Specificity

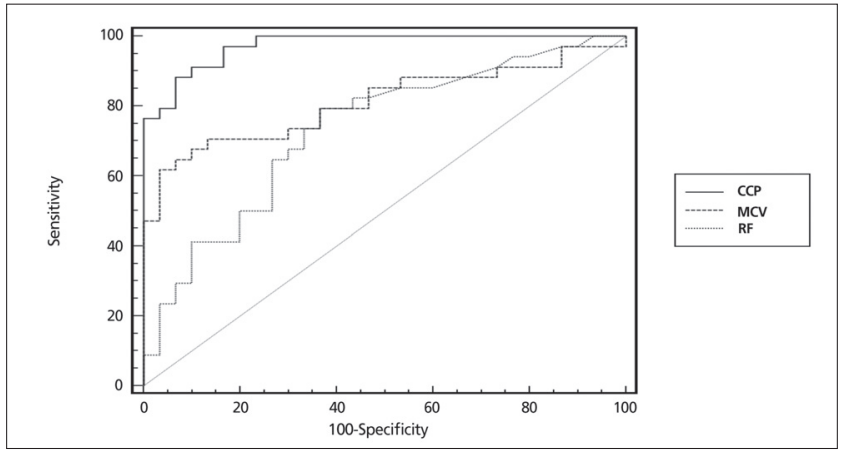

Figure 1. Analysis of diagnostic values of RF, anti-CCP and anti-MCV in patients with RA $(n=34)$ and hepatitis $C(n=30)$ CCP: cyclic citrullinated peptide, MCV: mutated citrullinated vimentin, RF: rheumatoid factor

The sensitivity and specificity of these auto-antibodies for RA vary in the literature between $55-84 \%$ and $77-98 \%$ for anti-CCP and $49-74 \%$ and $79-96 \%$ for anti-MCV, respectively $(7,8,10,14-20)$. The difference in the control groups of these studies might have evoked this diversity in the results. Some of them included healthy controls, some included autoimmune diseases, and some included both of them. Though there were results favoring anti-MCV over anti-CCP $(17,20)$, majority of these studies found anti-CCP more specific than anti-MCV for $\operatorname{RA}(7,8,10,15,17,19)$.

In our study, DAS-28 was weakly correlated with RF, anti-CCP, and anti-MCV. There were no differences between the active and mild active patients regarding RF, anti-CCP and anti-MCV levels. There are studies suggesting a significant correlation with disease activity $(8,14,15,18,21)$ while some others did not find any correlation $(16,20)$.

There was extra-articular involvement in 7 RA patients. No difference was found in autoantibody levels of patients with respect to extra-articular involvement which is consistent with the existing literature (10).

In HCV infection extra-hepatic involvements like arthralgia was frequent (23\%). Moreover asymptomatic joint involvement was detected by ultrasound in $96.5 \%$ of the patients (22). In our study there were 10 patients (33\%) with arthralgia among the hepatitis C patients. There was no difference between the patients with or without arthralgia regarding the autoantibody levels. A subgroup analysis of hepatitis $C$ patients according to the histological activity index and fibrosis was planned however the numbers of the patients were not adequate for statistical comparison.

There is only one study in the literature investigating the diagnostic performance of anti-MCV in RA including hepatitis C patients as controls (10). However their control group was not homogeneous regarding diagnosis and a subgroup analysis was not performed with the hepatitis $C$ patients. Their results favored specificity of anti-CCP.

In studies comparing anti-CCP and RF for distinguishing RA and hepatitis C patients, anti-CCP was found more specific. RF positivity was $37.5-54 \%$ whereas anti-CCP was positive in 0-5.7 in hepatitis $C$ patients (23-26). There are also a few conflicting results concluding that anti-CCP antibodies may be detected in hepatitis $C$ patients $(4,5)$. In one of these studies, some of the anti-CCP positive patients had erosions thereby suggesting coexistence.

It is well known that auto-antibodies may be positive in $\mathrm{HCV}$ infection without clinical involvement. HCV infection also establishes a linkage between extra-hepatic involvement and autoimmunity causing further confusion in evaluating the autoantibody responses (27). It is probable that citrullination and mutation of the vimentin encourages autoimmunity. Although citrullination plays a role in RA, the process is not specific and it has been detected e.g. in chronically inflamed tonsillar tissues (20). The role of mutation of vimentin in the pathogenesis of $\mathrm{HCV}$ infection needs to be clarified.

In conclusion; anti-MCV levels are high in RA, and it has a significant correlation with anti-CCP and disease activity. However its lower sensitivity and lower specificity suggest that it should be interpreted with caution especially in HCV patients. Currently, there is not an ideal assay for RA nevertheless anti-CCP seems to have proved itself amongst the opponents.

\section{Conflict of Interest}

No conflict of interest is declared by the authors. 


\section{References}

1. Klareskog L, Rönnelid J, Lundberg K, Padyukov L, Alfredsson L. Immunity to citrullinated proteins in rheumatoid arthritis. Annu Rev Immunol 2008; 26: 651-75.

2. Engelmann R, Brandt J, Eggert M, Karberg K, Krause A, Neeck G, et al. IgG1 and IgG4 are the predominant subclasses among auto-antibodies against two citrullinated antigens in RA. Rheumatology 2008; 47: 1489-92.

3. Sauerland U, Becker $H$, Seidel M, Schotte $H$, Willeke $P$, Schorat A, et al. Clinical utility of the anti-CCP assay. Experiences with 700 patients. Ann NY Acad Sci 2005; 1050: 314-8.

4. Riccio A, Postiglione L, La Dogana P, Spano A, Marzocchella C, Tarantino G. Anti-cyclic citrullinated peptide antibodies in patients affected by HCV-related arthritis. J Biol Regul Homeost Agents 2008; 22: 57-61.

5. Liu FC, Chao YC, Hou TY, Chen HC, Shyu RY, Hsieh TY, et al. Usefulness of anti-CCP antibodies in patients with hepatitis $C$ virus infection with or without arthritis, rheumatoid factor, or cryoglobulinemia. Clin Rheumatol 2008; 27: 463-7.

6. Palazzi C, D'Angelo S, Olivieri I. Hepatitis C virus-related arthritis. Autoimmunity Reviews 2008; 8: 48-51.

7. Mutlu N, Bicakcigil M, Tasan DA, Kaya A, Yavuz S, Ozden Al. Comparative performance analysis of 4 different anti-citrullinated protein assays in the diagnosis of rheumatoid arthritis. J Rheumatol 2009, 36: 491-500.

8. Wagner E, Skoumal M, Bayer PM, Klaushofer K. Antibody against mutated citrullinated vimentin: a new sensitive marker in the diagnosis of rheumatoid arthritis. Rheumatol Int 2009; 29: 1315-21.

9. Luime JJ, Colin EM, Hazes JM, Lubberts E. Does antiMCV has additional value as a serological marker in the diagnostic and prognostic work-up of patients with rheumatoid arthritis? A systematic review. Ann Rheum Dis 2010; 69: 337-44.

10. Sghiri R, Bouajina E, Bargaoui D, Harzallah L, Fredj HB, Sammoud S, et al. Value of anti-mutated citrullinated vimentin antibodies in diagnosing rheumatoid arthritis. Reumatol Int 2008; 29: 59-62.

11. Arnett FC, Edworthy SM, Bloch DA, McShane DJ, Fries JF, Cooper NS, et al. The American Rheumatism Association 1987 revised criteria for the classification of rheumatoid arthritis. Arthritis Rheum 1988; 31: 315-24.

12. Saag KG, Teng GG, Patkar NM, Anuntiyo J, Finney C, Curtis JR, et al. American College of Rheumatology 2008 recommendations for the use of nonbiologic and biologic disease-modifying antirheumatic drugs in rheumatoid arthritis. Arthritis Rheum 2008; 59: 762-84.

13. Ishak K, Baptista A, Bianchi L, Callea F, De Groote J, Gudat $F$, et al. Histological grading and staging of chronic hepatitis. J Hepatol 1995, 22:696-9.

14. Mathsson L, Mullazehi M, Wick MC, Sjöberg O, van Vollenhoven R, Klareskog $L$, et al. Higher sensitivity and extended prognostic value concerning future radiographic progression as compared with antibodies against cyclic citrullinated peptides. Arthritis Rheum 2008; 58: 36-45.
15. Nicaise Roland $P$, Grootenboer Mignot $S$, Bruns $A$, Hurtado M, Palazzo E, Hayem G, et al. Antibodies to mutated citrullinated vimentin for diagnosing rheumatoid arthritis in anti-CCP-negative patients and for monitoring infliximab therapy. Arthritis Res Ther 2008; 10:R142.

16. Ursum J, Nielen MM, van Schaardenburg $D$, van der Horst AR, van de Stadt RJ, Dijkmans BA, et al. Antibodies to mutated citrullinated vimentin and disease activity score in early arthritis: a cohort study. Arthritis Res Ther 2008; 10: R12.

17. Dejaco, C, Klotz W, Larcher H, Duftner C, Schirmer M, Herold M. Diagnostic value of antibodies against a modified citrullinated vimentin in rheumatoid arthritis. Arthritis Res Ther 2006; 8: R119.

18. Bang $H$, Egerer K, Gauliard A, Lüthke K, Rudolph $P E_{\text {, }}$ Fredenhagen $\mathrm{G}$, et al Mutation and citrullination modifies vimentin to a novel autoantigen for rheumatoid arthritis. Arthritis Rheum 2007; 56: 2503-11.

19. Innala L, Kokkonen H, Eriksson C, Jidell E, Berglin E, Dahlqvst SR. Antibodies against mutated citrullinated vimentin are better predictors of disease activity at 24 months in early rheumatoid arthritis than antibodies against cyclic citrullinated peptides. J Rheumatol 2008; 35: 1002-8.

20. Poulsom H, Charles PJ. Antibodies to citrullinated vimentin are a specific and sensitive marker for the diagnosis of rheumatoid arthritis. Clinic Rev Allerg Immunol 2008; 34: 4-10.

21. Kesgin G, Inal A, Kesgin D, Pekel A, Baysal O, Dizer U, et al. Diagnostic utility of anti-cyclic citrullinated peptide and anti-modified citrullinated vimentin antibodies in rheumatoid arthritis. Protein Pept Lett 2008; 15: 314-7.

22. Cacoub P, Poynard T, Ghillani P, Charlotte F, Olivi M, Piette JC, et al. Extrahepatic manifestations of chronic hepatitis C. Arthritis Rheum 1999; 42: 2204-12.

23. Lienesch D, Morris R, Metzger A, Depuys P, Sherman K. Absence of cyclic citrullinated peptide antibody in nonarthritic patients with chronic hepatitis C infection. J Rheumatol 2005; 32: 489-93.

24. Bombardieri M, Alessandri C, Labbadia G, Iannuccelli C, Carlucci F, Riccieri V, et al. Role of anti-cyclic citrullinated peptide antibodies in discriminating patients with rheumatoid arthritis from patients with chronic hepatitis C infection-associated polyarticular involvement. Arthritis Res Ther 2004; 6: R137-R141.

25. Koga T, Migita K, Miyashita T, Maeda Y, Nakamura M, Abiru $S$, et al. Determination of anti-cyclic citrullinated peptide antibodies in the sera of patients with liver diseases. Clin Exp Rheumatol 2008; 26: 121-4.

26. Sene D, Ghillani-Dalbin P, Limal N, Thibault V, van Boekel T, Piette JC, et al. Anti-cyclic citrullinated peptide antibodies in hepatitis $C$ virus associated rheumatological manifestations and Sjögren syndrome. Ann Rheum Dis 2008; 65: 394-7.

27. Muratori P, Muratori L, Verucchi G, Attard L, Bianchi FB, Lenzi M. Nonorgan specific autoantibodies in children with chronic hepatitis C: clinical significance and impact on interferon treatment. Clin Infect Dis 2003; 37: 1320-6. 